\title{
Epidemiology of the injury with venomous animals in the state of Rio Grande do Norte, Northeast of Brazil
}

\author{
Epidemiologia dos acidentes com animais peçonhentos \\ no estado do Rio Grande do Norte, Nordeste do Brasil
}

Aluska Vieira Tavares (https://orcid.org/0000-0003-1744-2203) ${ }^{1}$

Kalianny Adja Medeiros de Araújo (https://orcid.org/0000-0002-4835-177X) ${ }^{1}$

Michael Radan de Vasconcelos Marques (https://orcid.org/0000-0003-2141-7924) ${ }^{1}$

Renner Leite (https://orcid.org/0000-0003-0052-3840) ${ }^{1}$

${ }^{1}$ Centro de Educação e Saúde, Unidade Acadêmica de Saúde, Universidade Federal de Campina Grande. Olho D'água da Bica s/n. Cuité PB Brasil. aluskavieira@hotmail.com

\begin{abstract}
This report is an investigation of the epidemiological features of injuries with venomous animals in the Rio Grande do Norte state, Northeastern Brazil, from 2007 to 2014. A total of 30,429 cases were analyzed. Cases were distributed over all months of the period studied and occurred mainly in urban areas. Scorpion stings showed the highest percentage of cases, but the chance of death among snakebites was higher. Envenomation predominated in females with age between 20 and 49 years old. Children and elderly showed a higher chance of death. Most victims were bitten on the extremities of the limbs and received medical care within $0-1$ hour after being bitten. The main local and systemic symptoms reported were pain and headache, respectively. Cases were mostly classified as mild and progressed to cure. Few victims show local and systemic complications. The high number of accidents with venomous animals shows that Rio Grande do Norte may be an important risk area for such injuries. Furthermore, this study provides data for the development of health actions to promote control and prevention of these injuries in this region.
\end{abstract}

Key words Venomous animals, Envenomation, Public health
Resumo Este estudo é uma investigação das características epidemiológicas dos acidentes com animais peçonhentos no estado do Rio Grande do Norte, Nordeste do Brasil, de 2007 a 2014. Um total de 30.429 casos foram analisados. Os casos foram distribuídos em todos os meses do período estudado e ocorreram principalmente em áreas urbanas. Os acidentes escorpiônicos representaram maior percentual de casos, entretanto, a chance de morte entre acidentes ofídicos foi maior. Os envenenamentos predominaram em mulheres com idade entre 20 e 49 anos. Crianças e idosos exibiram maiores chances de morte. A maioria das vítimas foi picada nas extremidades dos membros e recebeu assistência médica entre 0-1 hora após o incidente. Os principais sintomas locais e sistêmicos reportados foram dor e cefaléia, respectivamente. Os casos foram principalmente classificados como leves e progrediram para cura. Poucas vítimas manifestaram complicações locais e sistêmicas. O elevado número de acidentes com animais peçonhentos indica que o estado do Rio Grande do Norte pode ser uma importante área de risco para tais acidentes. Além disso, este estudo fornece dados que poderão ser utilizados para a elaboração de ações em saúde, a fim de promover o controle e a prevenção desses acidentes nesta região.

Palavras-chave Animais peçonhentos, Envenenamento, Saúde pública 


\section{Introduction}

Accidents with venomous animals are a public health problem in Brazil due to high frequency in all regions of the country and potential severity ${ }^{1,2}$. In some cases, especially those caused by snakes, victims may develop sequelae that cause temporary or permanent incapacity to perform work and/or delays, or lead to death ${ }^{3}$. According to the Brazilian Health Ministry, cases of accidents with venomous animals have increased in recent years, from 31,746 in 2000 to 171,705 in 2016, with a total of $1,924,406$ cases in this period ${ }^{4}$. There has also been an increase in the number of deaths, which increased from 83 in 2000 to 326 in 2016, totaling 3,645 deaths. ${ }^{5}$. The Northeast region has the highest incidence of cases $(94 / 100,000$ inhabitants), followed by the South (93.8/100,000 inhabitants), North (85.3/100,000 inhabitants), Southeast (76.6/100,000 inhabitants) and Midwest $(59.3 / 100,000 \text { inhabitants })^{6}$.

Among the venomous animals responsible for most envenomation of medical importance there are snakes, scorpions, spiders, bees and caterpillars ${ }^{1}$. Scorpions are responsible for the largest number of accidents in Brazil ${ }^{3}$. They occur predominantly in urban areas ${ }^{7}$, with a higher risk of death in children ${ }^{8}$. The species of scorpions recognized for their medical importance in Brazil belong to the genus Tityus, namely T. serrulatus, T. bahiensis, T. obscurus, T. silvestris, T. metuendus, T. stigmurus and T. pusillus ${ }^{7}$. Snakebites mainly affects men living and working in rural areas'. Most cases are caused by snakes of the genera Bothrops, Crotalus, Lachesis and Micrurus. Bothrops accidents are the most frequent in all regions of Brazil, but Crotalus cases show the highest lethality rate $^{10}$. There are three genus of spiders of medical importance in Brazil: Phoneutria, Loxosceles and Latrodectus $^{11}$. Envenomation by spiders of the genus Loxosceles is characterized as the most severe and frequent, especially in the southern and southeastern regions of the country ${ }^{1,3}$.

African bees (Apis mellifera scutellata), characterized by their aggressive nature and high honey production, were introduced in Brazil in 1956. In the following year, there was an accidental release of some queens of this species, resulting in the hybridization or africanization of European bees (Apis mellifera mellifera and Apis mellifera ligustica) and uncontrolled mixed breeding of the Africanized species in the Brazilian environment. The frequency of serious and/or fatal envenomation caused by Africanized honey bee stings have increased since $1960^{12,13}$. Erucism is the name given to injuries caused by caterpillars of Lepidoptera in humans. The families mainly associated with injuries in Brazil are Megalopygidae, Saturniidae, Limacodidae and Arctiidae ${ }^{14}$. Caterpillars of genus Lonomia (Saturnidae family) have a greater relevance for public health, because they may provoke severe accidents or even deaths due hemorrhagic syndrome ${ }^{15}$. Chippaux ${ }^{3}$ shows that caterpillars, mainly those belonging to the genus Lonomia, were responsible for $4 \%$ of envenomation and 1\% of deaths provoked by venomous terrestrial animals. Envenomation predominated in males with no variation in incidence as a function of age, and cases were mostly classified as mild ${ }^{3}$.

The State of the Rio Grande do Norte, whose capital is Natal, is a federal unit that integrates the Northeast region of Brazil. It is composed of 167 municipalities, covering an area of 52,811,126 $\mathrm{km}^{2}$. These municipalities are distributed in four regions: Oeste Potiguar, Central Potiguar, Agreste Potiguar and Leste Potiguar. According to Instituto Brasileiro de Geografia e Estatística (IBGE), the total resident population of state is of $3,168,027$ inhabitants, with 2,464,991 living in urban areas and 703,036 in rural areas. The population density is of 60 inhabitants $/ \mathrm{km}^{2}$. Regarding gender, its population consists of about 1,548,887 men and $1,619,140$ women $^{16}$. In Rio Grande do Norte there are two climatic types: tropical and semiarid. The first takes place on the east coast, with more abundant rainfall, while the latter dominates almost all areas of the state, including the north coast. In the region of semiarid climate, rainfall is scarce and irregular. The majority of the territory of the Rio Grande do Norte (98\%) is located within the "Drought Polygon", an area that is affected annually by prolonged periods of drought. Almost the entire region has a low rainfall rate, high average temperatures, acute water deficits, generally thin and often salty soils, and caatinga vegetation. The average annual temperature in the state is $26^{\circ} \mathrm{C}$, with a maximum of $31^{\circ} \mathrm{C}$ and minimum of $21^{\circ} \mathrm{C}$. The rainy season occurs between the months of April to July and rainfall is below $600 \mathrm{~mm}$ annually ${ }^{17}$.

Although there is information provided by Brazilian Health Ministry on the annual incidence of the accidents with venomous animals in the State of Rio Grande do Norte, there is a lack of updated local and/or regional epidemiological information consistent with the medical importance of such envenomation. Moreover, there are few epidemiological studies on these injuries in the Northeastern Brazil, some cases are underre- 
ported and the epidemiological data collection is deficient. Finally, many social and environmental changes occurring in this region during recent decades have indicated that new research is needed to update the knowledge on this topic. To address this shortcoming, the current study analyzed epidemiological data regarding accidents with venomous animals recorded between 2007 and 2014 in the State of Rio Grande do Norte, northeastern Brazil.

\section{Methods}

\section{Study area}

The State of Rio Grande do Norte.

\section{Data collection}

Injury with venomous animals are mandatorily recorded by the National System of Notifiable Diseases [Sistema Nacional de Agravos de Notificação (SINAN) ${ }^{18}$ based on medical records used in the investigation and follow-up of cases of injury with venomous animals. The SINAN is a national electronic surveillance system which contains a variety of diseases in an integrated database that also includes venomous animals ${ }^{19}$. All cases of accidents with venomous animals in the State of Rio Grande do Norte recorded to SINAN from 2007 to 2014 were included in the current study. Epidemiological data was analyzed according to gender and age of the victim, year and month of the incident, area of occurrence (urban or rural) of the case, part of the body stung, time elapsed until medical care, severity and progression of the case, local and systemic manifestations and local and systemic complications. Demographic and population data from the Instituto Brasileiro de Geografia e Estatística were used to calculate the incidence rates for accidents with venomous animals.

\section{Spatial distribution}

The map was prepared with the software QGIS 2.8, using estimates of the average incidence by municipality. The incidence rate was calculated as the ratio of cases by the population of each municipality, estimated for every 100,000 inhabitants. Spatial interpolation of the incidence of cases was mapped using data from 167 municipalities and it was performed by the Inverse Distance Weight method ${ }^{20}$.

\section{Statistical analysis}

Statistical analyses were performed using the Chi-square (Likelihood Ratio Chi-Square) test and Correspondence Analysis (ANACOR), Mann-Whiney and Kruskal-Wallis and Odds Ratio tests. The level of significance was $p<0.05$. All statistical analyses were performed using the software SPSS ${ }^{\varpi}$ version 22.0 (Statistical Package for Social Sciences) for Windows.

\section{Ethical clearance}

This study was carried out on the basis of secondary database. The authors did not have access to the nominal data of the accident victims or any other data that would allow identification and they were in compliance with ethics legislation/ recommendations of research in the country.

\section{Results}

There have been reported 30,429 cases of accidents with venomous animals in the State of Rio Grande do Norte, from January 2007 to December 2014. Scorpion stings showed the highest percentage of cases $(n=20,554 ; 67.5 \%)$, followed by snakebites ( $\mathrm{n}=3,019 ; 9.9 \%)$, honey bees $(\mathrm{n}=$ $2,168 ; 7.1 \%)$ and spiders $(n=1,073 ; 3.5 \%)(\mathrm{Ta}-$ ble 1). Graph 1 shows that the cases of accidents increased between the period of 2007 to 2011 . Among 2011 and 2012 the cases decreased and from 2013 occurred an increase in the number of cases. Graph 2 shows that the cases occurred in all months of the investigated years, with the highest frequency in August $(n=2,733 ; 9 \%)$ and September $(n=2,735 ; 9 \%)$.

Regarding the spatial distribution of cases, the average incidence rates were irregularly distributed in the state, with values between 0 and 947,255 cases/100,000 inhabitants (Figure 1). The most significant incidence rates were reported in the Leste and Agreste Potiguar region, namely, São Gonçalo do Amarante, Natal, Extremoz, Barcelona, Ruy Barbosa, São José do Campestre and Monte das Gameleiras.

Table 1 shows that the majority of cases involved female subjects $(\mathrm{n}=16,521 ; 54.3 \%)$ when compared with males ( $\mathrm{n}=13,908 ; 45.7 \%)$. Women were most affected in cases of scorpion stings and the envenomation caused by snakes, honey bees, spiders, caterpillars and other animals affected mainly men, who presented a higher chance of death $(\mathrm{OR}=2.49 ; 95 \% \mathrm{CI}: 1.21-5.10)$. 
Table 1. Distribution of the accidents with venomous animals in the State of Rio Grande do Norte, from 2007 to 2014 , according to the type of aggressor animal, area of occurrence, aged, time elapsed until medical care and part of body affected by injury.

\begin{tabular}{|c|c|c|c|c|c|c|c|}
\hline \multirow{2}{*}{ Variables } & \multicolumn{2}{|c|}{ Female } & \multicolumn{2}{|c|}{ Male } & \multicolumn{2}{|c|}{ Total } & \multirow{2}{*}{$\begin{array}{c}\text { Odds ratio } \\
\text { OR (CI: Upper limit - Lower limit) }\end{array}$} \\
\hline & $\mathbf{n}$ & $\%$ & $\mathbf{n}$ & $\%$ & $\mathbf{n}$ & $\%$ & \\
\hline \multicolumn{8}{|l|}{ Agressor animal } \\
\hline Snake & 715 & 4.3 & 2,304 & 16.6 & 3,019 & 9.9 & $\mathrm{OR}=5.64(\mathrm{IC} 95 \%: 2.82-11.28)$ \\
\hline Spider & 516 & 3.1 & 557 & 4.0 & 1,073 & 3.5 & $\mathrm{OR}=0.83(\mathrm{IC} 95 \%: 0.11-6.07)$ \\
\hline Scorpion & 12,67 & 76.6 & 7,885 & 56.7 & 20,55 & 67.5 & $\mathrm{OR}=0.43(\mathrm{IC} 95 \%: 0.22-0.84)$ \\
\hline Caterpillar & 134 & 0.8 & 142 & 1.0 & 276 & 0.9 & 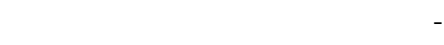 \\
\hline Bee & 779 & 4.7 & 1,389 & 10.0 & 2,168 & 7.1 & $\mathrm{OR}=1.26(\mathrm{IC} 95 \%: 0.39-4.13)$ \\
\hline Other & 783 & 4.7 & 848 & 6.1 & 1,631 & 5.4 & 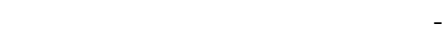 \\
\hline Unknown & 925 & 5.6 & 783 & 5.6 & 1,708 & 5.6 & $\mathrm{OR}=0.30(\mathrm{IC} 95 \%: 0.00-0.22)$ \\
\hline \multicolumn{8}{|l|}{ Victim's age (years) } \\
\hline $0|-| 9$ & 1,535 & 9.3 & 1,865 & 13.4 & 3,4 & 11.2 & $\mathrm{OR}=3.81(\mathrm{IC} 95 \%: 1.86-7.83)$ \\
\hline $10|-| 19$ & 2,222 & 13.4 & 2,152 & 15.5 & 4,374 & 14.4 & $\mathrm{OR}=1.03(\mathrm{IC} 95 \%: 0.40-2.66)$ \\
\hline $20|-| 29$ & 3,154 & 19.1 & 2,977 & 21.4 & 6,131 & 20.1 & $\mathrm{OR}=0.25(\mathrm{IC} 95 \%: 0.06-1.03)$ \\
\hline $30|-| 39$ & 2,665 & 16.1 & 2,369 & 17.0 & 5,034 & 16.5 & $\mathrm{OR}=0.32(\mathrm{IC} 95 \%: 0.08-1.32)$ \\
\hline $40|-| 49$ & 2,729 & 16.5 & 1,857 & 13.4 & 4,586 & 15.1 & $\mathrm{OR}=0.55(\mathrm{IC} 95 \%: 0.17-1.78)$ \\
\hline $50|-| 59$ & 1,995 & 12.1 & 1,315 & 9.5 & 3,31 & 10.9 & $\mathrm{OR}=0.79(\mathrm{IC} 95 \%: 0.24-2.59)$ \\
\hline $60|-| 69$ & 1,277 & 7.7 & 820 & 5.9 & 2,097 & 6.9 & $\mathrm{OR}=1.31(\mathrm{IC} 95 \%: 0.40-4.28)$ \\
\hline $70|-| 79$ & 668 & 4.0 & 416 & 3.0 & 1,084 & 3.6 & $\mathrm{OR}=2.62(\mathrm{IC} 95 \%: 0.80-8.60)$ \\
\hline$\geq 80$ & 276 & 1.7 & 137 & 1.0 & 413 & 1.4 & $\mathrm{OR}=4.56(\mathrm{IC} 95 \%: 1.09-19.09)$ \\
\hline \multicolumn{8}{|c|}{ Geographical location of the case } \\
\hline Urban & 14,29 & 86.5 & 10,21 & 73.4 & 24,51 & 80.5 & $\mathrm{OR}=0.17(\mathrm{IC} 95 \%: 0.09-0.33)$ \\
\hline Rural & 1,417 & 8.6 & 2,73 & 19.6 & 4,147 & 13.6 & $\mathrm{OR}=8.06(\mathrm{IC} 95 \%: 4.09-15.87)$ \\
\hline Periurban & 112 & 0.7 & 119 & 0.9 & 231 & 0.8 & 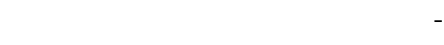 \\
\hline Unknown & 698 & 4.2 & 845 & 6.1 & 1,543 & 5.1 & $\mathrm{OR}=0.57(\mathrm{IC} 95 \%: 0.08-4.15)$ \\
\hline \multicolumn{8}{|c|}{ Time from bite until assistance $(\mathrm{h})$} \\
\hline $0-1 \mathrm{~h}$ & 5,659 & 34.3 & 4,487 & 32.3 & 10,15 & 33.3 & $\mathrm{OR}=0.52(\mathrm{IC} 95 \%: 0.23-1.19)$ \\
\hline $1-3 \mathrm{~h}$ & 4,2 & 25.4 & 3,499 & 25.2 & 7,699 & 25.3 & $\mathrm{OR}=0.51(\mathrm{IC} 95 \%: 0.20-1.32)$ \\
\hline $3-6 h$ & 1,705 & 10.3 & 1,532 & 11.0 & 3,237 & 10.6 & $\mathrm{OR}=2.18(\mathrm{IC} 95 \%: 0.95-5.01)$ \\
\hline $6-12 \mathrm{~h}$ & 957 & 5.8 & 722 & 5.2 & 1,679 & 5.5 & $\mathrm{OR}=1.66(\mathrm{IC} 95 \%: 0.51-5.43)$ \\
\hline $12-24 \mathrm{~h}$ & 873 & 5.3 & 633 & 4.6 & 1,506 & 4.9 & $\mathrm{OR}=1.86(\mathrm{IC} 95 \%: 0.57-6.09)$ \\
\hline$>24$ & 895 & 5.4 & 745 & 5.4 & 1,64 & 5.4 & $\mathrm{OR}=1.10(\mathrm{IC} 95 \%: 0.26-4.58)$ \\
\hline Unknown & 2,232 & 13.5 & 2,29 & 16.5 & 4,522 & 14.9 & $\mathrm{OR}=1.49(\mathrm{IC} 95 \%: 0.65-3.41)$ \\
\hline \multicolumn{8}{|l|}{ Affected part of the body } \\
\hline Head & 496 & 3.0 & 932 & 6.7 & 1,428 & 4.7 & $\mathrm{OR}=0.62(\mathrm{IC} 95 \%: 0.08-4.50)$ \\
\hline Arm & 577 & 3.5 & 524 & 3.8 & 1,101 & 3.6 & $\mathrm{OR}=1.67(\mathrm{IC} 95 \%: 0.40-6.96)$ \\
\hline Forearm & 386 & 2.3 & 356 & 2.6 & 742 & 2.4 & - \\
\hline Hand & 1,861 & 11.3 & 1,705 & 12.3 & 3,566 & 11.7 & $\mathrm{OR}=0.73(\mathrm{IC} 95 \%: 0.22-2.39)$ \\
\hline Finger & 3,486 & 21.1 & 2,476 & 17.8 & 5,962 & 19.6 & $\mathrm{OR}=0.26(\mathrm{IC} 95 \%: 0.06-1.07)$ \\
\hline Trunk & 636 & 3.8 & 662 & 4.8 & 1,298 & 4.3 & $\mathrm{OR}=2.18(\mathrm{IC} 95 \%: 0.66-7.12)$ \\
\hline Thigh & 647 & 3.9 & 418 & 3.0 & 1,065 & 3.5 & 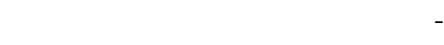 \\
\hline Leg & 618 & 3.7 & 654 & 4.7 & 1,272 & 4.2 & $\mathrm{OR}=0.69(\mathrm{IC} 95 \%: 0.10-5,08)$ \\
\hline Foot & 4,333 & 26.2 & 3,363 & 24.2 & 7,696 & 25.3 & $\mathrm{OR}=3.49(\mathrm{IC} 95 \%: 1.57-7.80)$ \\
\hline Toe & 2,042 & 12.4 & 1,353 & 9.7 & 3,395 & 11.2 & $\mathrm{OR}=1.37(\mathrm{IC} 95 \%: 0.53-3.55)$ \\
\hline Unknown & 1,439 & 8.7 & 1,465 & 10.5 & 2,904 & 9.5 & $\mathrm{OR}=1.26(\mathrm{IC} 95 \%: 0.44-3.59)$ \\
\hline Total & 16,521 & $100 \%$ & 13,908 & $100 \%$ & 30,429 & $100 \%$ & 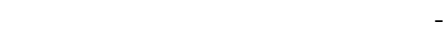 \\
\hline
\end{tabular}




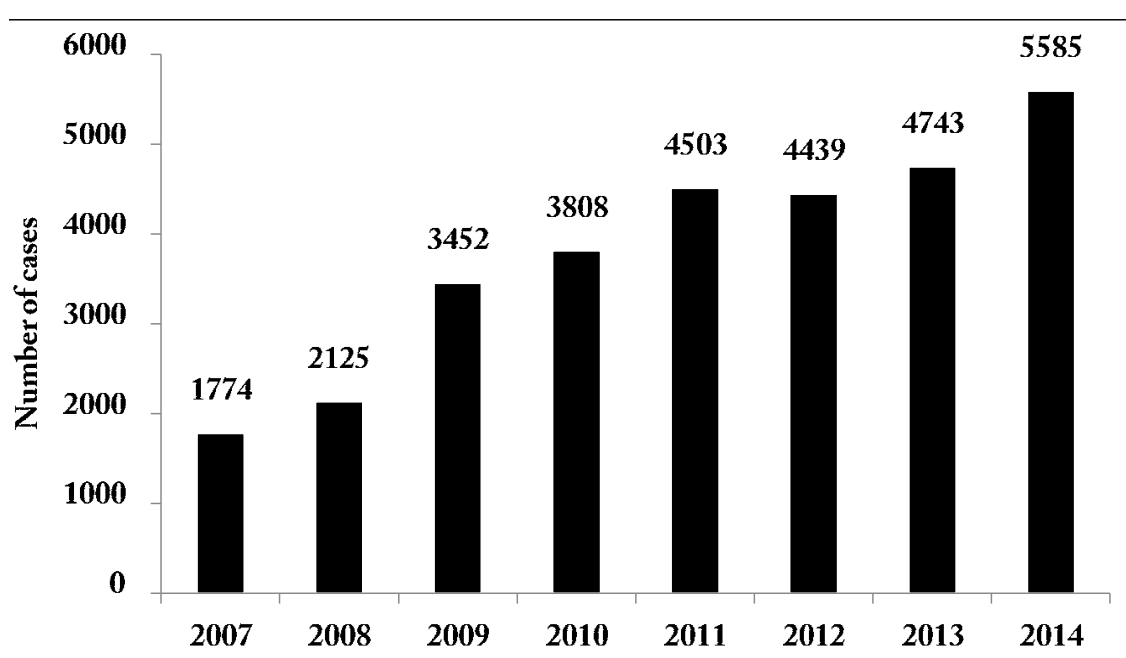

Graphic 1. Distribution by year of the accidents with venomous animals in the State of Rio Grande do Norte, from 2007 to 2014.

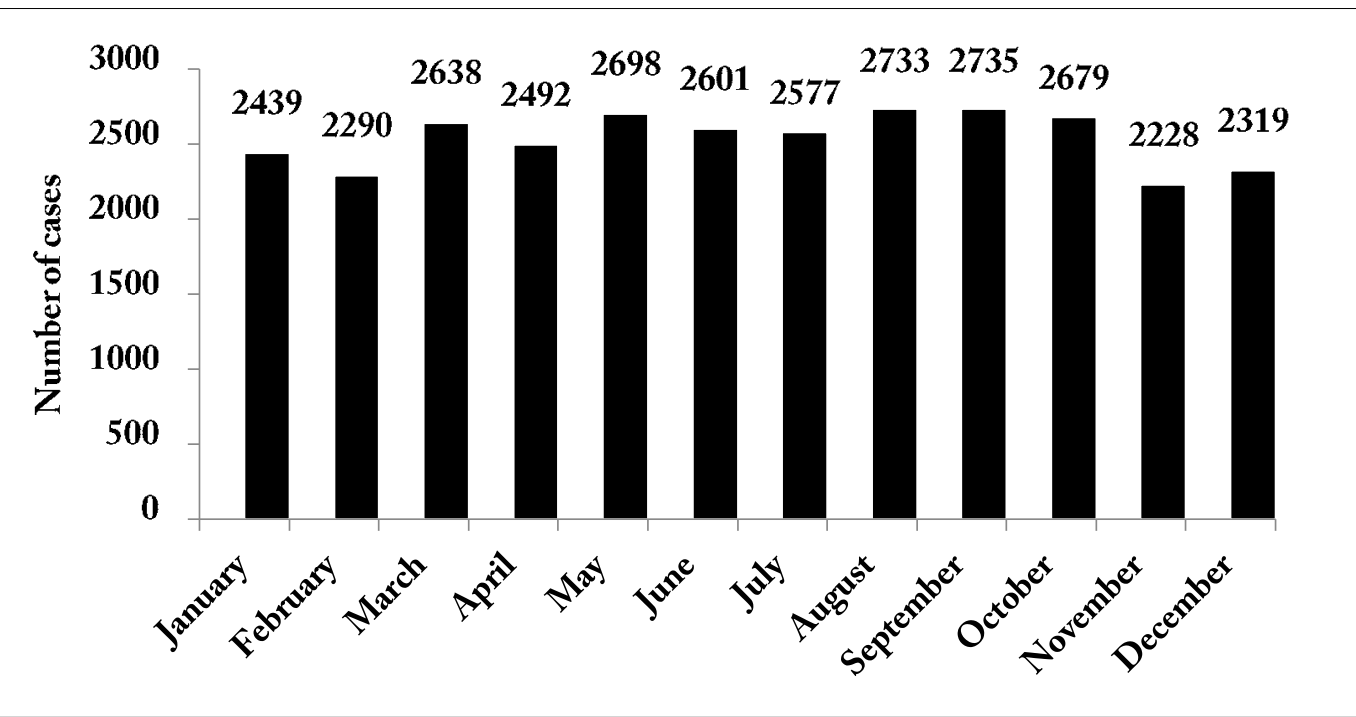

Graphic 2. Distribution by month of the accidents with venomous animals in the State of Rio Grande do Norte, from 2007 to 2014.

There was a predominance of cases involving individuals between 20 and 29 years of age $(\mathrm{n}=$ $6,131 ; 20.1 \%)$, followed by the age range between 30 and 39 years $(\mathrm{n}=5,034 ; 16.5 \%)$ and 40 to 49 years $(\mathrm{n}=4,586 ; 15.1 \%)$. Individuals aged up to 9 years old $(\mathrm{OR}=3.81 ; 95 \% \mathrm{CI}: 1.86-7.83)$ and between 80 years or more $(\mathrm{OR}=4.56$; $95 \% \mathrm{CI}$ : 1.09 - 19.09) have a higher chance of death. Accidents occurred predominantly in the urban areas ( $\mathrm{n}=24,508 ; 80.5 \%)$ and less frequently in rural areas $(\mathrm{n}=4,147 ; 13 \cdot 6 \%)$. Accidents in rural areas have a higher chance of death (OR $=8.06$; $95 \%$ CI: 4.09 - 15.87) when compared to those in urban areas. Most of the victims received medical care between 0 and 1 hour after the accident $(\mathrm{n}=$ 10,$146 ; 33.3 \%$ ) and between 1 and 3 hours after the accident $(\mathrm{n}=7,699 ; 25.3 \%)$. The stings affected mainly the extremities of the body, such as the foot $(n=7,696 ; 25.3 \%)$, followed by the finger $(n=5,962 ; 19.6 \%)$, hand $(n=3,566 ; 11.7 \%)$ 

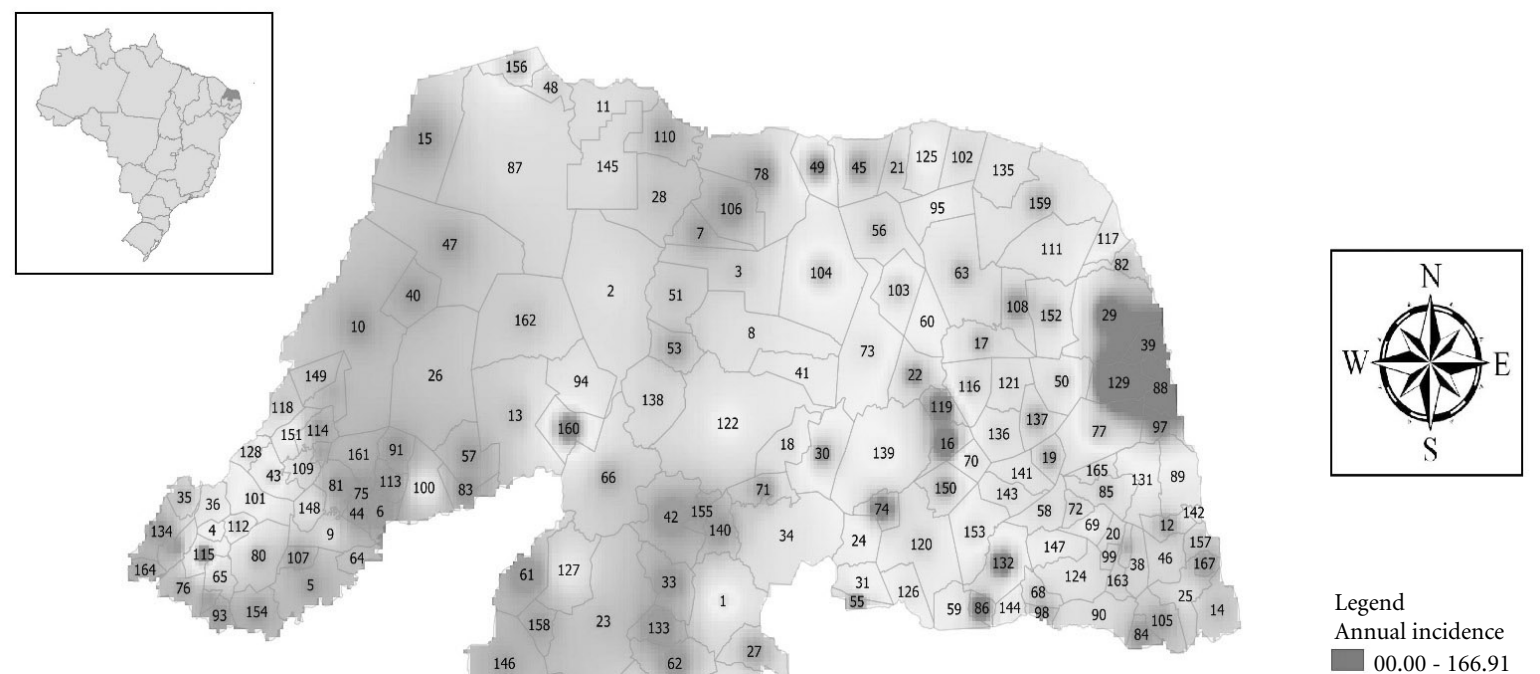

Legend

Annual incidence

$\square 00.00$ - 166.91

$166.91-361.99$

$361.99-557.08$

$557.08-752.17$

$752.17-947.25$

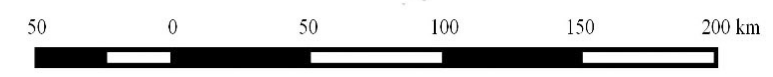

\begin{tabular}{|c|c|c|c|c|c|c|c|c|c|c|c|c|c|}
\hline Acari & 1 & Canguaretama & 25 & Guamaré & 49 & Lajes & 73 & Parnamirim & 97 & Santa Maria & 121 & Serra do Mel & 145 \\
\hline Açu & 2 & Caraúbas & 26 & Ielmo Marinho & 50 & Lajes Pintadas & 74 & Passa-e-Fica & 98 & Santana do Matos & 122 & Serra Negra do Norte & 146 \\
\hline Afonso Bezerra & 3 & $\begin{array}{l}\text { Carnaúba dos } \\
\text { Dantas }\end{array}$ & 27 & Ipanguaçu & 51 & Lucrécia & 75 & Passagem & 99 & Santana do Seridó & 123 & Serrinha & 147 \\
\hline Água Nova & 4 & Carnaubais & 28 & Ipueira & 52 & Luís Gomes & 76 & Patu & 100 & Santo Antônio & 124 & Serrinha dos Pintos & 148 \\
\hline Alexandria & 5 & Ceará-Mirim & 29 & Itajá & 53 & Macaíba & 77 & Pau dos Ferros & 101 & São Bento do Norte & 125 & Severiano Melo & 149 \\
\hline Almino Afonso & 6 & Cerro Corá & 30 & Itaú & 54 & Macau & 78 & Pedra Grande & 102 & São Bento do Trairi & 126 & Sítio Novo & 150 \\
\hline Alto do Rodrigues & 7 & $\begin{array}{l}\text { Coronel } \\
\text { Ezequiel }\end{array}$ & 31 & Jaçanã & 55 & Major Sales & 79 & Pedra Preta & 103 & São Fernando & 127 & Taboleiro Grande & 151 \\
\hline Angicos & 8 & $\begin{array}{l}\text { Coronel João } \\
\text { Pessoa }\end{array}$ & 32 & Jandaíra & 56 & $\begin{array}{l}\text { Marcelino } \\
\text { Vieira }\end{array}$ & 80 & Pedro Avelino & 104 & São Francisco do Oeste & 128 & Taipu & 152 \\
\hline Antônio Martins & 9 & Cruzeta & 33 & Janduís & 57 & Martins & 81 & Pedro Velho & 105 & $\begin{array}{l}\text { São Gonçalo do } \\
\text { Amarante }\end{array}$ & 129 & Tangará & 153 \\
\hline Apodi & 10 & Currais Novos & 34 & Januário Cicco & 58 & Maxaranguape & 82 & Pendências & 106 & São João do Sabugi & 130 & Tenente Ananias & 154 \\
\hline Areia Branca & 11 & \begin{tabular}{|l} 
Doutor \\
Severiano
\end{tabular} & 35 & Japi & 59 & $\begin{array}{l}\text { Messias } \\
\text { Targino }\end{array}$ & 83 & Pilões & 107 & São José de Mipibu & 131 & $\begin{array}{l}\text { Tenente Laurentino } \\
\text { Cruz }\end{array}$ & 155 \\
\hline Arês & 12 & Encanto & 36 & Jardim de Angicos & 60 & Montanhas & 84 & Poço Branco & 108 & São José do Campestre & 132 & Tibau & 156 \\
\hline Augusto Severo & 13 & Equador & 37 & Jardim de Piranhas & 61 & Monte Alegre & 85 & Portalegre & 109 & São José do Seridó & 133 & Tibau do Sul & 157 \\
\hline Baía Formosa & 14 & Espírito Santo & 38 & Jardim do Seridó & 62 & $\begin{array}{l}\text { Monte das } \\
\text { Gameleiras }\end{array}$ & 86 & Porto do Mangue & 110 & São Miguel & 134 & $\begin{array}{l}\text { Timbaúba dos } \\
\text { Batistas }\end{array}$ & 158 \\
\hline Baraúna & 15 & Extremoz & 39 & João Câmara & 63 & Mossoró & 87 & Pureza & 111 & São Miguel do Gostoso & 135 & Touros & 159 \\
\hline Barcelona & 16 & Felipe Guerra & 40 & João Dias & 64 & Natal & 88 & Rafael Fernandes & 112 & São Paulo do Potengi & 136 & Triunfo Potiguar & 160 \\
\hline Bento Fernandes & 17 & $\begin{array}{l}\text { Fernando } \\
\text { Pedroza }\end{array}$ & 41 & José da Penha & 65 & Nísia Floresta & 89 & Rafael Godeiro & 113 & São Pedro & 137 & Umarizal & 161 \\
\hline Bodó & 18 & Florânia & 42 & Jucurutu & 66 & Nova Cruz & 90 & Riacho da Cruz & 114 & São Rafael & 138 & Upanema & 162 \\
\hline Bom Jesus & 19 & \begin{tabular}{|l} 
Francisco \\
Dantas
\end{tabular} & 43 & Jundiá & 67 & $\begin{array}{l}\text { Olho-d'Água } \\
\text { do Borges }\end{array}$ & 91 & Riacho de Santana & 115 & São Tomé & 139 & Várzea & 163 \\
\hline Brejinho & 20 & $\begin{array}{l}\text { Frutuoso } \\
\text { Gomes }\end{array}$ & 44 & Lagoa d'Anta & 68 & Ouro Branco & 92 & Riachuelo & 116 & São Vicente & 140 & Venha-Ver & 164 \\
\hline Caiçara do Norte & 21 & Galinhos & 45 & Lagoa de Pedras & 69 & Paraná & 93 & Rio do Fogo & 117 & Senador Elói de Souza & 141 & Vera Cruz & 165 \\
\hline $\begin{array}{l}\text { Caiçara do Rio do } \\
\text { Vento }\end{array}$ & 22 & Goianinha & 46 & Lagoa de Velhos & 70 & Paraú & 94 & Rodolfo Fernandes & 118 & $\begin{array}{l}\text { Senador Georgino } \\
\text { Avelino }\end{array}$ & 142 & Viçosa & 166 \\
\hline Caicó & 23 & $\begin{array}{l}\text { Governador } \\
\text { Dix-Sept } \\
\text { Rosado }\end{array}$ & 47 & Lagoa Nova & 71 & Parazinho & 95 & Ruy Barbosa & 119 & Serra Caiada & 143 & Vila Flor & 167 \\
\hline Campo Redondo & 24 & Grossos & 48 & Lagoa Salgada & 72 & Parelhas & 96 & Santa Cruz & 120 & Serra de São Bento & 144 & & \\
\hline
\end{tabular}

Figure 1. Spatial distribution of the accidents with venomous animals in the State of Rio Grande do Norte, from 2007 to 2014. 
Table 2. Distribution of the accidents with venomous animals in the State of Rio Grande do Norte, from 2007 to 2014, according to the severity, progression, clinical manifestations and clinical complications.

\begin{tabular}{|c|c|c|c|c|c|c|}
\hline & \multicolumn{2}{|c|}{ Female } & \multicolumn{2}{|c|}{ Male } & \multicolumn{2}{|c|}{ Total } \\
\hline & $\mathbf{n}$ & $\%$ & $\mathbf{n}$ & $\%$ & $\mathbf{n}$ & $\%$ \\
\hline \multicolumn{7}{|l|}{ Severity } \\
\hline Mild & 15,588 & 94.4 & 12,274 & 88.3 & 27,862 & 91.6 \\
\hline Moderate & 353 & 2.1 & 736 & 5.3 & 1,089 & 3.6 \\
\hline Severe & 38 & 0.2 & 92 & 0.7 & 130 & 0.4 \\
\hline Unknown & 542 & 3.3 & 806 & 5.8 & 1,348 & 4.4 \\
\hline \multicolumn{7}{|l|}{ Progression } \\
\hline Cure & 15,456 & 93.6 & 12,481 & 89.7 & 27,937 & 91.8 \\
\hline Death by venomous animals & 11 & 0.1 & 23 & 0.2 & 34 & 0.1 \\
\hline Death by other causes & 1 & 0.0 & 0 & 0.0 & 1 & 0.0 \\
\hline Unknown & 1,053 & 6.4 & 1,404 & 10.1 & 2,457 & 8.1 \\
\hline \multicolumn{7}{|l|}{ Local manifestations } \\
\hline Pain & 14,472 & 93.5 & 11,316 & 90.6 & 25,788 & 92.2 \\
\hline Paresthesia & 7,468 & 48.3 & 4,636 & 37.1 & 12,104 & 43.3 \\
\hline Swelling & 5,698 & 36.8 & 5,393 & 43.2 & 11,091 & 39.7 \\
\hline Hyperemia & 3,032 & 19.6 & 1,78 & 14.3 & 4,812 & 17.2 \\
\hline Injury & 412 & 2.7 & 340 & 2.7 & 752 & 2.7 \\
\hline Erythema & 360 & 2.3 & 332 & 2.7 & 692 & 2.5 \\
\hline Ecchymosis & 242 & 1.6 & 426 & 3.4 & 668 & 2.4 \\
\hline Cramp & 212 & 1.4 & 114 & 0.9 & 326 & 1.2 \\
\hline Hypoaesthesia & 187 & 1.2 & 123 & 1.0 & 310 & 1.1 \\
\hline Redness & 108 & 0.7 & 90 & 0.7 & 198 & 0.7 \\
\hline Necrosis & 19 & 0.1 & 40 & 0.3 & 59 & 0.2 \\
\hline \multicolumn{7}{|l|}{ Systemic manifestations } \\
\hline Headache & 377 & 28.9 & 285 & 23.5 & 662 & 26.3 \\
\hline Vagal & 154 & 11.8 & 200 & 16.5 & 354 & 14.1 \\
\hline Fever & 160 & 12.3 & 119 & 9.8 & 279 & 11.1 \\
\hline Sweating & 170 & 13.0 & 95 & 7.8 & 265 & 10.5 \\
\hline Neuroparalytic & 69 & 5.3 & 166 & 13.7 & 235 & 9.3 \\
\hline Nausea & 175 & 13.4 & 56 & 4.6 & 231 & 9.2 \\
\hline Dizziness & 102 & 7.8 & 106 & 8.8 & 208 & 8.3 \\
\hline Miolytic/hemolytic & 38 & 2.9 & 114 & 9.4 & 152 & 6.0 \\
\hline Chill & 77 & 5.9 & 50 & 4.1 & 127 & 5.1 \\
\hline Tremors & 71 & 5.4 & 38 & 3.1 & 109 & 4.3 \\
\hline Renal & 20 & 1.5 & 62 & 5.1 & 82 & 3.3 \\
\hline Vomit & 42 & 3.2 & 18 & 1.5 & 60 & 2.4 \\
\hline Dyspnea & 26 & 2.0 & 30 & 2.5 & 56 & 2.2 \\
\hline Agitation & 29 & 2.2 & 11 & 0.9 & 40 & 1.6 \\
\hline \multicolumn{7}{|l|}{ Local complications } \\
\hline Secondary infection & 38 & 76.0 & 50 & 72.5 & 88 & 73.9 \\
\hline Functional deficit & 9 & 18.0 & 11 & 15.9 & 20 & 16.8 \\
\hline Necrosis & 5 & 10.0 & 4 & 5.8 & 9 & 7.6 \\
\hline Amputation & 1 & 2.0 & 1 & 1.4 & 2 & 1.7 \\
\hline Compartment syndrome & 1 & 2.0 & 0 & 0.0 & 1 & 0.8 \\
\hline \multicolumn{7}{|l|}{ Systemic complications } \\
\hline Respiratory failure/acute pulmonary edema & 11 & 42.3 & 19 & 50.0 & 30 & 46.9 \\
\hline Renal & 10 & 38.5 & 18 & 47.4 & 28 & 43.8 \\
\hline Shock & 6 & 23.1 & 8 & 21.1 & 14 & 21.9 \\
\hline Septicaemia & 0 & 0.0 & 2 & 5.3 & 2 & 3.1 \\
\hline
\end{tabular}


and toe $(\mathrm{n}=3,395 ; 11.2 \%)$. The cases where the stings occurred in the foot $(\mathrm{OR}=3.49 ; 95 \% \mathrm{CI}$ : $1.57-7.80$ ) has a greater chance of death.

Table 2 shows that most cases exhibit mild severity ( $\mathrm{n}=27,862 ; 91.6 \%)$, some cases moderate severity $(\mathrm{n}=1,089 ; 3.6 \%)$ and few severe cases $(\mathrm{n}=130 ; 0.4 \%)$. The moderate $(\mathrm{OR}=3.60$; $95 \%$ CI: $1.27-10.24)$ and severe $(\mathrm{OR}=160.20$; 95\% CI: 78.36 - 327.52) cases showed a higher chance of death in relation to mild cases. There was also a significant association between the severity of the case and the type of aggressor animal $(\chi 2=4,501.44 ; \mathrm{p}<0.05)$. Correspondence analysis shows that snakebites are more associated with moderate and severe cases. Our results also show a significant association between the severity of the case with the area of occurrence $\left(\chi^{2}=4,310.55 ; \mathrm{p}<0.05\right)$ and the time elapsed between the sting and the medical care $(\chi 2=$ $1,674.19 ; \mathrm{p}<0.05)$. Regarding the progression of the case, the majority progressed to cure ( $\mathrm{n}$ $=27,937 ; 91.8 \%)$ and 34 cases of deaths were recorded, resulting in lethality rate of $0.1 \%$. A significant association between the progression of the case, area of occurrence $(\chi 2=1550.39$; $p$ $<0.05)$ and time elapsed between the sting and medical care $(\chi 2=800.33 ; p<0.05)$. It was also observed a significant association between the type of aggressor animal and the progression of the case $(\chi 2=702.06 ; p<0.05)$. Snakebites were more likely to progress to death $(\mathrm{OR}=5.64,95 \%$ CI: 2.82 - 11.28).

Table 2 also shows that 27,963 cases $(91.9 \%)$ exhibited local symptoms, while 2,514 (8.3\%) manifested systemic symptoms. The main local manifestation was pain $(\mathrm{n}=25,788 ; 92.2 \%)$, followed by paresthesia ( $\mathrm{n}=12,104 ; 43.3 \%)$, edema $(\mathrm{n}=11,091 ; 39.7 \%)$ and hyperemia $(\mathrm{n}=4,812$; 17.2\%). Regarding systemic manifestations, headache predominated $(n=662 ; 26.3 \%)$, followed by vagal manifestations ( $\mathrm{n}=354 ; 14.1 \%)$, fever $(\mathrm{n}=279 ; 11.1 \%)$ and sweating $(\mathrm{n}=265$; $10.5 \%)$. The most frequent local complications were: secondary infection $(\mathrm{n}=88 ; 73.9 \%)$, functional deficit $(\mathrm{n}=20 ; 16.8 \%)$ and necrosis $(\mathrm{n}=$ 9; $7.6 \%$ ). In relation to systemic complications, there were mainly edema $(\mathrm{n}=30 ; 46.9 \%)$, renal complications $(\mathrm{n}=28 ; 43.8 \%)$ and shock $(\mathrm{n}=$ $14 ; 21 \%)$.

\section{Discussion}

The current study shows that there was an increase of venomous animal injury cases in Rio
Grande do Norte from 2007 to 2016. In this period, a total of 30,429 cases were recorded by the Health Department of Rio Grande do Norte, with an average of 3,804 cases per year. The annual average incidence rate was of 117,36 cases/100,000 inhabitants, which is in agreement with that reported by the Brazilian Health Ministry ${ }^{6}$. Most of the envenomation were caused by scorpions (67.5\%), followed by snakes $(9.9 \%)$ and honey bees $(7.1 \%)$. Similar results were described by Barbosa ${ }^{21}$ in a study also carried out in Rio Grande do Norte, pointing out scorpions, snakes and honey bees as the main aggressor animals. Taken together, these results suggest that Rio Grande do Nortemay be considered as a risk area to such envenomation in the northeast of the Brazil.

The occurrence of cases in all municipalities of the state indicates a wide spatial distribution of venomous animals in this region. Highest incidences were reported in the municipalities located in the regions of the Leste and Agreste Potiguar, mainly in the regions of Natal, Macaíba and Borborema Potiguar. The Leste Potiguar region is the most populous of the state and in it is the capital, Natal, as well as the Metropolitan region of $\mathrm{Natal}^{16}$. The regions of Natal and $\mathrm{Ma}$ caíba have a population of $1,030,764$ and 288,836 inhabitants, respectively ${ }^{16}$. In these regions there were predominance of accidents with scorpions that may be due to high population density. Lima et al..$^{22}$ reported that scorpion sting is common in urban areas due to population density, inefficient basic sanitation, garbage accumulation, and lack of a natural predator. The increase of the scorpion envenomation in large urban areas has also been described in studies carried out in the Northeast of Brazil, such as: Lira-da-Silva et al. ${ }^{23}$ in the State of the Bahia and Barros et al. ${ }^{24}$ in the State of the Paraíba. The region of Agreste Potiguar is the third most populous of the state ${ }^{16}$. In the region of Borborema Potiguar there were predominance of ophidian cases. According to Instituto Brasileiro de Geografia e Estatística, this region has a population of 134,027 inhabitants and stands out as being a region of high agricultural and pastoral activities ${ }^{16,25,26}$. The prevalence of ophidian accidents in this region may be a result of the high number of individuals working with agro-pastoral activities. These activities favor the encounter of the individual with the snakes, which may increase the possibility of occurrence of the incidents ${ }^{27}$.

Although an increase in the number of cases was observed, the annual variation was not statis- 
tically significant between the period studied ( $\mathrm{p}=$ $0.43)$, which is in agreement with data provided by the Brazilian Health Ministry ${ }^{4}$. The incidence of injury with venomous animals is related to seasonal factors, which may change according to the region $^{28,29}$. Chippaux ${ }^{3}$ reported that the incidence of cases is stable throughout the year in all the regions of Brazil, except in the South, where the incidence decreases during the winter months. Our results show a slight increase in cases reported between August and September, but without significant monthly variation $(\mathrm{p}=0.99)$. The uniform distribution of cases in all months of the studied years may be attributed to the stable climatic conditions of the region, which is characterized by low seasonal amplitudes, low precipitation, high luminosity and high average temperature ${ }^{30}$.

Most of the cases involved women (54.3\%), agreeing with the study performed by Barbosa ${ }^{21}$ in the State of Rio Grande do Norte, as well with the SINITOX ${ }^{31}$. However, higher chance of death was between men, probably due to the larger exposure of these individuals to accidents with snakes, honey bees and spiders, which are more lethal. Our results about the aggressor animal seem to reinforce that the men are the most affected by accidents with snakes, honey bees and spiders. Moreover, the men have a greater chance of progression to death, since the accidents with these animals also resulted in the highest rates of lethality, being 0.43 (snakes); 0.14 (honey bees) and 0.9 (spiders). The majority of the cases affected individuals aged between 20 and 49 years old (51.7\%), indicating that the economically active population of the region investigated is the most affected by the accidents. These results are in agreement with the study carried out in State of Mato Grosso by Santana and Suchara $^{32}$ and by data provided by the Brazilian Health Ministry ${ }^{33}$. Individuals aged up to 9 years old and between 80 years or more represent a smaller number of total medical records but have a higher chance of death.

The prevalence of cases in urban areas $(80.5 \%)$ is in agreement with the study of Barbosa $^{21}$ and with the findings reported by the Instituto Butantan ${ }^{29}$. The increase of such accidents is due to the easy adaptation of scorpions to life in an urban environment ${ }^{34}$. This characteristic has been described in several epidemiological investigations in the Northeast region of Brazil ${ }^{24,35}$. Although accidents occurring in rural areas represent a lower percentage of cases $(13.6 \%)$, they have a higher chance of death (OR $=8.06 ; 95 \%$ CI: 4.09 - 15.87) when compared to those in urban areas. The increased chance of death may be due to the difficulty of accessing the victims to the health center. Tavares et al. ${ }^{27}$ in an investigation conducted in Rio Grande do Norte, also indicated a higher chance of death among the cases occurred in rural areas. Cases received medical care predominantly between 0 and 1 hour (33.3\%) after the accident $(\mathrm{p}<0.05)$, which is in agreement with the epidemiological studies carried out in the North region ${ }^{36}$, Midwestregion ${ }^{32}$ and Southeastern Brazil ${ }^{37}$.

The extremities of the body (foot and hand) were the anatomical regions most affected by the stings or bites, totaling $68 \%$ of the cases. Injury often occurs when individuals perform activities such as putting on shoes, wearing clothes, manipulating building materials, performing farming or cleaning activities, without using personal protective equipment. This may explain the increased frequency of pricking at the extremities of the limbs. The cases where the stings occurred in the foot showed a greater chance of death. In our results, the greater chance of death among bites that affected the foot may be due to the high number of accidents caused by snakes, which are more lethal.

Regarding the severity of the cases, the majority were classified as mild $(91.6 \%)$, followed by moderate $(3.6 \%)$ and severe $(0.4 \%)$ cases $(\mathrm{p}$ $<0.05)$. The moderate and severe cases showed a higher chance of death in relation to mild cases. Similar results were reported in studies carried out in the State of Mato Grosso by Silva et al. ${ }^{38}$ and in the State of Minas Gerais by Ladeira and Machado $^{39}$. There was also a significant association between the severity of the case and the type of aggressor animal $(\chi 2=4,501.44 ; \mathrm{p}<0,05)$. Correspondence analysis shows that snakebites are more associated with moderate and severe cases. This may be explained due to the greater toxicity of snake venom ${ }^{40}$. Accidents with scorpions, honey bees and spiders were more associated to mild cases. Our results also show a significant association between the area of occurrence and the severity of the case $(\chi 2=4,310.55 ; \mathrm{p}<0.05)$. Envenomation in urban areas were more associated to mild cases, while accidents occurring in rural areas were more associated with moderate and severe cases. In rural areas, victims take more time to move to the nearest health facility. The graphical distances obtained on the perceptual map show that the time elapsed between the sting and the medical care may influence the severity of the cases $(\chi 2=1,674.19 ; \mathrm{p}<0.05)$. Mild cases are more associated with shorter time gaps, from 0 to 1 hour and from 1 to 3 hours. On the 
other hand, moderate and severe cases are more associated with longer time gaps. These results indicate that delays in medical care may influence the severity of the cases.

Most of the cases progressed to cure (91.8\%) and 34 to death, of which 16 were caused by scorpions, 13 by snakes, 3 by honey bees, 1 by spiders and in 1 case the animal causing the accident was unknown. A strong association also was found between the type of aggressor animal and the progression of the case $(\chi 2=702.06 ; \mathrm{p}<0.05)$. In current study, snakebite cases were more likely to progress to death, followed by honey bee sting cases. Importantly, the largest number of severe envenomation with systemic complications and manifestations was among ophidian accidents. In fact, snake venom is probably the most complex and deadly of all poisons of venomous animals of medical importance ${ }^{40}$. On the other hand, Lopes et al..$^{36}$ showed that in the North of Brazil the highest lethality rates were of the cases with honey bees $(0.59 \%)$ and snakes $(0.47 \%)$. Moreover, Forrester et al. ${ }^{41}$, showed that honey bee envenomation progress to death more frequently than those caused by snakes, scorpions and spiders. This may be due to hypersensitivity reactions induced by honey bee stings and/or even by the absence of a specific treatment with antivenom. Hypersensitivity reactions may be caused by a single sting and lead to death due to glottal edema or anaphylactic shock ${ }^{12,13}$. It was also observed significant association between the progression of the case, area of occurrence $(\chi 2=1,550.39 ; \mathrm{p}<$ $0.05)$ and time elapsed between the sting and the medical care $(\chi 2=800.33 ; \mathrm{p}<0.05)$. Accidents occurring in rural areas and those with delays in medical care are more associated with death. This data indicates that the chance of a case progressing to death is associated with late medical care, favored by the distance between the rural area and the nearest health facility.

Most deaths occurred in rural areas (55.9\%) and involved predominantly men $(67.6 \%)$ between 0 and 9 years old $(32.4 \%)$ and over than 50 years old $(32.4 \%)$. Bites reached mainly the foot $(38.2 \%)$. Deaths were predominant among accidents with bees (41.1\%) and snakes (38.2\%). The majority of victims sought medical care tardly, between 3 and more than 24 hours after being bitten (44.1\%). Regarding the clinical manifestations $88.2 \%$ of cases show local manifestations, while $38.2 \%$ show systemic manifestations. In relation to severity, there was a predominance of mild (38.2\%) and severe (38.2\%) cases. Only $8.8 \%$ of individuals who evolved to death exhib- ited local complications and 35.3\% exhibited systemic complications.

The main local manifestations were pain (92.2\%), paresthesia $(43.3 \%)$ and swelling (39.7\%). The most frequent systemic manifestations were headache $(26.3 \%)$, vagal manifestations (14.1\%), fever (11.1\%) and sweating $(10.5 \%)$. These results are in agreement with the local and systemic manifestations reported in the Brazilian literature ${ }^{11,27,42}$. The highest proportion of victims did not show local and/or systemic complications. The prevalence of complications was among cases of snakebites. The main local complications were infection (73.9\%), functional deficit (16.8\%) and necrosis (7.6\%). Secondary infection has been reported mainly in ophidi$\mathrm{an}^{43}$ and spider accidents ${ }^{44}$. The functional deficit occurs mainly in ophidian accidents ${ }^{40,45}$. Necrosis is also described in accidents with snakes ${ }^{46}$, spiders $^{46}$, caterpillars ${ }^{47}$, ants ${ }^{48}$, and some species of venomous fish ${ }^{49,50}$. The main systemic complications were: edema $(46.9 \%)$, renal failure $(43.8 \%)$ and shock (21.9\%). Renal insufficiency and shock are the most common complications in accidents with snakes ${ }^{46}$ and honey bees ${ }^{13}$. Glottis edema is a frequent complication reported in cases of bee stings, which can lead victims to death ${ }^{13}$. Acute pulmonary edema and shock have also been described in cases of scorpion stings ${ }^{51}$ and renal failure among spider accidents ${ }^{46}$.

In conclusion, accidents with venomous animals may be considered an environmental public health problem in the state of Rio Grande do Norte which needs to be monitored and controlled throughout the year. The occurrence of cases in all municipalities indicates the wide dispersion of venomous animals in the state. Therefore, the findings of the current study increase the understanding of epidemiology of injury by venomous animals in the state and will be useful in identifying the conditions that increase the risk of envenomation in northeastern Brazil.

\section{Collaborations}

AV Tavares worked in the analysis, interpretation data, and wrote the first version of the article. KAM Araújo and MRV Marques worked in the survey of the literature, in the research and methodology. R Leite worked on the conception and design the study, final approval of the version of the article to be published. 


\section{References}

1. Oliveira RC, Wen FH, Sifuentes DN. Epidemiologia dos acidentes por animais peçonhentos. In: Cardoso JL, Haddad-Jr V, França FOS, Wen FH, Malaque CMS, editors. Animais peçonhentos do Brasil: biologia, clínica e terapêutica. São Paulo: Sarvier; 2009. p. 6-21.

2. Silva AM, Bernarde PS, Abreu LC. Accidents with poisonous animals in Brazil by age and sex. J Hum Growth Dev 2015; 25(1):54-62.

3. Chippaux JP. Epidemiology of envenomations by terrestrial venomous animals in Brazil based on case reporting: from obvious facts to contingencies. J Venom Anim Toxins Incl Trop Dis 2015; 21(13):1-17.

4. Brasil. Ministério da Saúde (MS). Sistema de Informação de Agravos de Notificação. Série histórica de casos - Acidentes por animais peçonhentos [Internet]. Brasília: MS; 2017. [cited 2017 July 27]. Available from: http://portalarquivos.saude.gov.br/images/ pdf/2017/abril/28/1-SerieHistorica_1986-2016.pdf

5. Brasil. Ministério da Saúde (MS). Sistema de Informação de Agravos de Notificação. Óbitos - Acidentes por animais peçonhentos [Internet]. Brasília: MS; 2017. [cited 2017 July 27]. Available from: http:// portalarquivos.saude.gov.br/images/pdf/2017/ abril/28/3-Obitos_AnimaisPeconhentos_2000_2016. pdf

6. Brasil. Ministério da Saúde (MS). Sistema de Informação de Agravos de Notificação. Incidência (/100.000 habitantes) - Acidentes por animais peçonhentos [Internet]. Brasília: MS; 2017. [cited 2017 July 27]. Available from: http://portalarquivos.saude.gov.br/images/ pdf/2017/abril/28/2-Incidencia_AnimaisPeconhentos_2000_2016.pdf

7. Reckziegel GC, Pinto Jr VL. Scorpionism in Brazil in the years 2000 to 2012. J Venom Anim Toxins Incl Trop Dis 2014; 20(46):1-8.

8. Bahloul M, Chabchoub I, Chaari A, Chtara K, Kallel H, Dammak H,Ksibi H, Chelly H, Rekik N, Hamida $\mathrm{CB}$, Bouaziz M. Scorpion envenomation among children: clinical manifestations and outcome (analysis of 685 cases). Am J Trop Med Hyg 2010; 83(5):1084-1092.

9. Bochner R, Struchiner CJ. Epidemiologia dos acidentes ofídicos nos últimos 100 anos no Brasil: uma revisão. Cad Saude Publica 2003; 19(1):7-16.

10. Brasil. Ministério da Saúde (MS). Fundação Nacional da saúde. Manual de diagnóstico e tratamento de acidentes por animais peçonhentos [Internet]. $2^{\mathrm{a}}$ ed. Brasília: FUNASA; 2001. [cited 2017 April 15]. Available from: http://portalsaude.saude.gov.br/images/ pdf/2014/marco/14/Manual-de-Diagnostico-e-Tratamento-de-Acidentes-por-Animais-Pe--onhentos.pdf

11. Cupo P, Marques MMA, Hering SE. Acidentes por animais peçonhentos: escorpiões e aranhas. Urgências Emergências Dermatol Toxicol 2003; 36(2/4):480-489.
12. Ferreira RS, Almeida RAMB, Barravieira SRCS, Barravieira V. Historical Perspective and human consequences of africanized bee stings in the Americas. $J$ Toxicol Environ Health 2012; 15(2):97-108.

13. Almeida RAMB, Olivo TET, Mendes RP, Barraviera SRCS, Souza LR, Martins JG Hashimoto M, Fabris VE, Ferreira Junior RS, Barraviera B. Africanized honey bee stings: how to treat them. Rev Soc Bras Med Trop 2011; 44(6):755-761.

14. Moraes RHP. Lepidópteros de Importância médica In: Cardoso JL, Haddad-Jr V, França FOS, Wen FH, Malaque CMS, editors. Animais peçonhentos do Brasil: biologia, clínica e terapêutica. São Paulo: Sarvier; 2009. p. 227-235.

15. Arocha-Piñango CL, Guerrero B. Hemorrhagic syndrome induced by caterpilars: Clinical and experimental studies. Invest Clin 2003; 44(2):155-163.

16. Instituto Brasileiro de Geografia e Estatística (IBGE). Estados@: Rio Grande do Norte [Internet]. Brasília: IBGE; 2010. [cited 2016 June 15]. Available from: http://www.ibge.gov.br/estadosat/perfil. php?sigla=rn

17. Universidade Federal de Santa Catarina (UFSC). Centro Universitário de Estudos e Pesquisas sobre Desastres (CEPED). Atlas brasileiro de desastres naturais 1991 a 2010: volume Rio Grande do Norte [Internet]. Florianópolis: CEPED, UFSC; 2011 [cited 2016 June 15]. Available from: http://www.mi.gov.br/documents/10157/156218/Atlas+Rio+Grande+do+Norte. pdf/c79f8574-da1d-401e-96dd-84e914dd8c74?version $=1.0$

18. Brazil. Law No. 104 of January 25, 2011. It defines the terminologies adopted in national legislation, in accordance with the provisions of the International Health Regulations 2005 (IHR 2005), the list of diseases, injuries and public health events of compulsory notification throughout the national territory and establishes the flow, criteria, responsibilities and professionals and health services. Diário Oficial da União 2011; 25 Jan.

19. Bochner R, Struchiner CJ. Acidentes por animais peçonhentos e sistemas nacionais de informação. Cad Saude Publica 2002; 18(3):735-746.

20. Shepard D. A two-dimensional interpolation function for irregularly-spaced data. Proceedings of the 1968 ACM National Conference 1968; 517-524.

21. Barbosa IR. Clinical and epidemiological aspects of accidents caused by venomous animals in the Rio Grande do Norte State. Rev Cien Plural 2015; 1(3):213.

22. Lima ALM, Lima JA De, Souto MCDS, Lopes TFDC, Torres UPDS, Maciel ACC. Spatial distribution and epidemiological profile of scorpion accidents in $\mathrm{Na}-$ tal/RN. ConScientiae Saude 2011; 10(4):627-633. 
23. Lira-da-Silva RM, Amorim AM, Carvalho FM, Brazil TK. Acidentes por escorpião nacidade de Salvador, Bahia, Brasil (1982-2000). Gaz Med Bahia 2009; 79(Supl. 1):43-49.

24. Barros RM, Pasquino JA, Peixoto LR, Targino ITG, Sousa JA, Leite, RS. Clinical and epidemiological aspects of scorpion stings in the Northeast region of Brazil. Cien Saude Colet 2014; 19(4):1275-1282.

25. Cuenca MA, Mandarino DC. Mudanças na geografia agrícola no âmbito de microrregiões: Rio Grande do Norte, 1990 e 2004 [Internet]. Aracaju: Embrapa; 2007. [cited 2017 July 15]. Available from: http:// www.cpatc.embrapa.br/publicacoes_2007/Doc-102.pdf

26. Serviço de Apoio às Micro e Pequenas Empresas (SEBRAE). Diagnóstico da cadeia produtiva agroindustrial da caprinovinocultura do Rio Grande do Norte: comportamento da cadeia produtiva agroindustrial da caprinovinocultura do Rio Grande do Norte. Natal: SEBRAE; 2001.

27. Tavares AV, Araújo KAM, Marques MRV, Viera AA, Leite RS. The epidemiology of snakebite in the Rio Grande do Norte State, Northeastern Brazil. Rev Inst Med Trop São Paulo 2017; 59(e52):1-10.

28. Brasil. Ministério da Saúde (MS). Secretaria de Vigilância em Saúde. Guia de vigilância epidemiológica [Internet]. 6a ed. Brasília: MS; 2005. [cited 2017 April 19]. Available from: http:// bvsms.saude.gov.br/bvs/ publicacoes/Guia_Vig_Epid_novo2.pdf

29. Brasil. Hospital Vital Brazil. Instituto Butantan. Acidentes por animais peçonhentos [Internet]. São Paulo: Instituto Butantan; 2000 [cited 2017 July 21]. Available from: http://www.saude.sp.gov.br/resources/cve-centro-de-vigilancia-epidemiologica/areas-de-vigilancia/ doencas-de-transmissao-por-vetores-e-zoonoses/ aula03_peconhentos.pdf

30. Companhia Energética do Rio Grande do Norte (COSERN). Potencial eólico do estado do Rio Grande do Norte [Internet]. Rio Grande do Norte; 2003 [cited 2017 July 21]. Available from: http://www.cresesb.cepel.br/publicacoes/download/atlas_eolico/atlas_eolico_RN.pdf

31. Brasil. Ministério da Saúde (MS). Sistema de Informação de Agravos de Notificação. Manual de controle de escorpiões [Internet]. Brasília: MS; 2009 [cited 2017 July 27]. Available from: http://bvsms.saude.gov.br/ bvs/publicacoes/manual_controle_escorpioes.pdf

32. Santana VTP, Suchara EA. Epidemiologia dos acidentes com animais peçonhentos registrados em Nova Xavantina - MT. Rev Epidemiol Control Infect 2015; 5(3):141-146.

33. Brasil. Ministério da Saúde (MS). Sistema de Informação de Agravos de Notificação. Acidentes por animais peçonhentos - Análise dos dados epidemiológicos de 2014 [Internet]. Brasília: MS; 2014 [cited 2017 July 27]. Available from: http://portalarquivos.saude. gov.br/images/pdf/2016/maio/20/Informe-Epidemiol--gico-animais-pe--onhentos---.pdf

34. Alves RS, Martins RD, Souza DF, Alves CD, Barbosa PSF, Queiroz MGR, Martins AMC, Monteiro HSA. Aspectos epidemiológicos dos acidentes escorpiônicos no estado do Ceará no período de 2003 a 2004. REPM 2007; 1(3):14-20.

35. Araújo KAM, Tavares AV, Marques MRV, Vieira AA, Leite RS. Epidemiological study of scorpion stings in the Rio Grande do Norte State, Northeastern Brazil. Rev Inst Med Trop Sao Paulo 2017; 59(e58):1-9.
36. Lopes AB, Oliveira AA, Dias FCF, Santana VMX, Oliveira VS, Liberato AA, Calado EJR, Lobo PHP, Gusmão KE, Guedes VR. Epidemiological profile of accidents of venomous animals in North region between 2012 and 2015: A Review. Rev Patol Tocantins 2017; 4(2):36-40.

37. Silveira JL, Machado C. Epidemiology of accidents by venomous animals in the South of Minas Gerais. J Health NPEPS 2017; 2(1):88-101.

38. Silva JH, Giansante S, Silva RCR, Silva GB, Silva LB, Pinheiro LCB. Perfil epidemiológico dos acidentes com animais peçonhentos em Tangará da Serra-MT, Brasil (2007-2016). J Health NPEPS 2017; 2(1):5-15.

39. Ladeira CGP, Machado C. Epidemiologia dos acidentes com animais peçonhentos na região de Ponte Nova, Minas Gerais, Brasil. J Health NPEPS 2017; 2(1):40-57.

40. França FO, Málaque CM. Acidente botrópico. In: Cardoso JL, França FO, Wen FH, Málaque CM, Haddad Jr V, editors. Animais peçonhentos no Brasil: biologia, clínica e terapêutica dos acidentes. 2a ed. São Paulo: Sarvier; 2009. p.81-95.

41. Forrester JA, Holstege CP, Forrester JD. Fatalities from venomous and nonvenomous animals in the United States (1999-2007). Wilderness Environ Med 2012; 23(2):146-152.

42. Linard ATS, Barros RM, Sousa JA, Leite RS. Epidemiology of bee stings in Campina Grande, Paraíba state, Northeastern Brazil. J Venom Anim Toxins Incl Trop Dis 2014; 20(13):1-6.

43. Silva PRGVF, Vilela RVR, Possa AP. Secondary infeccions in snakebite accidents: a bibliographic evaluation. EVS PUC Goiás 2016; 43(1):17-26.

44. Guerra AFP, Reis FC, Pessoa AM, Silva Jr NJ. Perfil dos acidentes com aranhas no estado de Goiás no período de 2007 a 2011. Scientia Medica 2014; 24(4):353-360.

45. Santos KC, Almeida MM, Pessoa AM, Sadd VA, Silva Jr NJ. Systematic review: the main complications of accident bothropic. EVS PUC Goiás 2016; 43(1):7178.

46. Warrell DA. Venomous animals. Medicine 2012; 40(3):159-163.

47. Haddad Jr V, Cardoso JL. Erucismo e Lepidopterismo. In: Cardoso JL, França FO, Wen FH, Málaque CM, Haddad Jr V, editors. Animais peçonhentos no Brasil: biologia, clínica e terapêutica dos acidentes. $2^{\mathrm{a}}$ ed. São Paulo: Sarvier; 2009. p.237-252.

48. Koya S, Crenshaw D, Agarwal A. Rhabdomyolysis and Acute Renal Failure After Fire Ant Bites. J Gen Intern Med 2007; 22(1):145-147.

49. Haddad Jr V. Acidentes por animais aquáticos Brasileiros. In: Cardoso JL, França FO, Wen FH, Málaque CM, Haddad Jr V, editors. Animais peçonhentos no Brasil: biologia, clínica e terapêutica dos acidentes. 2a ed. São Paulo: Sarvier; 2009. p.283-294.

50. Haddad Jr V. Animais aquáticos de importância médica no Brasil. Rev Soc Bras Med Trop 2003; 36(5):591597.

51. Cupo P. Clinical update on scorpion envenoming. Rev Soc Bras Med Trop 2015; 48(6):642-649.

Article submitted on $07 / 02 / 2018$

Approved on 11/09/2018

Final version submitted on 13/09/2018 